\title{
Optical Resolution and Absolute Configuration of the Peripheral Vasodilator Xanthinol Nicotinate
}

\author{
DAVID GRACE, ${ }^{a}$ HANS HAMMER ${ }^{b}$ and ARNE J. AASEN ${ }^{b}$
}

a Department of Chemistry, University of Oslo, Box 1033, Blindern, 0315 Oslo 3, Norway, and ${ }^{6}$ Department of Chemistry, The Agricultural University of Norway, Box 30, N 1432 As - NLH, Norway

Xanthinol nicotinate ${ }^{1}\left(\right.$ Complamin $\left.^{R}\right)$ which is used in the treatment of peripheral and cerebral vascular diseases, ${ }^{2,3}$ consists of the salt of nicotinic acid and the basic, racemic theophylline derivative xanthinol $(1,( \pm)$-3,7-dihydro-7-[2-hydroxy-3-[(2-hydroxyethyl)methylamino]propyl]-1,3-dimethyl-1H-purine-2,6-dione). The optical resolution and assignment of absolute configuration of xanthinol constitute the subject of the present communication.

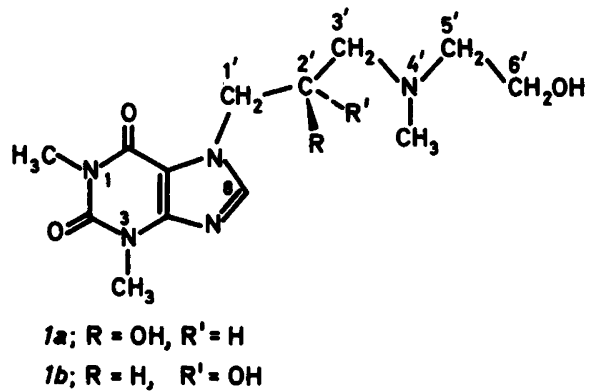

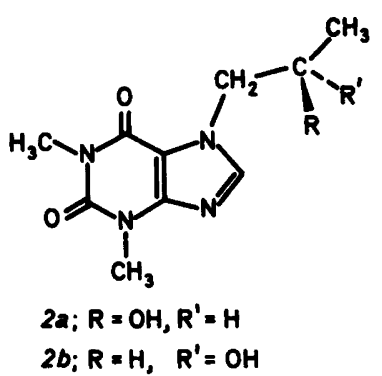

The enantiomers of racemic xanthinol $(1)$ were readily separated using $(+)$-camphor-10sulfonic acid as resolving agent. Fractional crystallization of the diastereomeric salts from isopropanol and ethanol-isopropanol mixtures furnished one of the salts essentially pure as judged from the optical purity of (-)-xanthinol isolated on decomposition of the salt. The enantiomeric purity was assessed by the addition of a chiral solvating agent, $(S)-(+)-2,2,2-$ trifluoro-1-(9-anthryl)ethanol, to the ${ }^{1} \mathrm{H}$ NMR solution according to the method described by Pirkle et al. .,5 $^{(-)}$-Xanthinol was thus obtained virtually optically pure and, as the result of comparing its CD curve with that of the structurally closely-related $(R)-(-)$-proxyphylline $(2 a)$, the absolute configuration of $(-)$-xanthinol is considered to be $(R)(l a) ; c f$. Fig. 1 . The configurations of $(R)$ - and $(S)$-proxyphylline $(2 a$ and $2 b)$ have been established by syntheses from theophylline and $(R)$ - and $(S)$-propylene oxide derived from $(S)$-alanine ${ }^{6}(=\mathrm{L}-\mathrm{Ala})$, and $(S)$-ethyl lactate, ${ }^{6,7}$ respectively.

The resonances in the ${ }^{1} \mathrm{H}$ NMR spectrum of (-)-xanthinol were assigned with the help of a homocorrelated $2 \mathrm{D}$ (COSY) spectrum.

Experimental. Melting points were determined on a Reichert melting point apparatus and are uncorrected. Analyses were performed by Novo Microanalytical Laboratory, DK-2880 Bagsvaerd, Denmark. Optical rotations, IR spectra, and mass spectra were recorded on Carl Zeiss, Perkin Elmer 597, and Micromass 7070F instruments, respectively. ${ }^{1} \mathrm{H}$ NMR spectra were recorded on Varian XL-300 and Jeol GX 400 spectrometers. CD spectra were obtained at ambient temperature using a Jobin-Yvon Dichrograph IV; solvent: water, light-path: $0.5 \mathrm{~mm}$; concentration: $1 \mathrm{mg} \mathrm{ml}^{-1}$; scan rate: $20 \mathrm{~nm} \mathrm{~min}^{-1}$; further details are given in Ref. 8.

Ion exchange chromatography. Xanthinol (1), being freely soluble in water, was separated from the acidic moiety of its salts by passing an aqueous solution of the salt through an anion exchange column, CG-400, followed by removal of the water in vacuo.

Enantiomeric composition. Addition of $(S)-(+)-2,2,2$-trifluoro-1-(9-anthryl)ethanol ${ }^{4,5}$ to the ${ }^{1} \mathrm{H}$ NMR solution of $( \pm)$-xanthinol $(1)$ induced spectral nonequivalence of the 


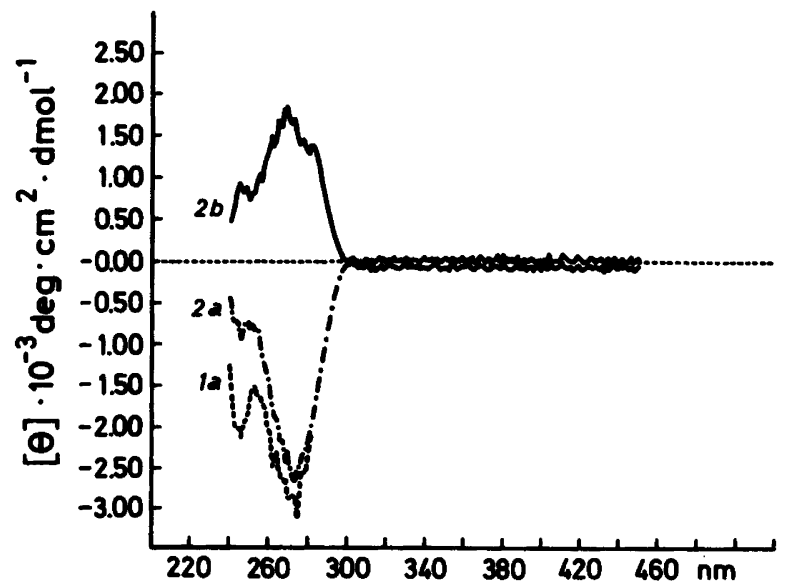

Fig. 1. CD curves of $(R)-(-)$-xanthinol $(1 a),(R)-(-)$-proxyphylline $(2 a)$, and $(S)-(+)-$ proxyphylline $(2 b)$ in water.

diastereomeric solvates and, thus, revealed that the method of Pirkle et al. ${ }^{4,5}$ for determination of enantiomeric purity is applicable for optically active xanthinol. Most of the xanthinol resonances exhibited non-equivalence with a 7.6:1 molar ratio of chiral solvating agent to substrate, and in particular, the $\mathrm{H}-8$ resonance was well separated from other resonances and was completely resolved into two singlets. Integration then permitted reliable quantification of the enantiomeric composition. It is worth noting that these resonances are obscured by the chiral reagent aromatic protons when lower ratios are used.

( \pm )-Xanthinol (1). Decomposition of xanthinol nicotinate $\left(\right.$ Complamin $\left.{ }^{R}\right)$, obtained from Astra Farmasøytiske A/S, N.1473 Skårer, Norway, on a CG-400 column furnished (士)-xanthinol: $m / z(E I, \%): 293\left(\mathrm{M}^{+}-18,0.2\right), 280(5), 114(4), 89(5), 88(100), 81(4), 58$ (10); $\mathrm{m} / z$ (CI, \%, isobutane): $312(100), 294$ (2), $114(4), 88$ (46); ${ }_{\mathrm{H}} \mathrm{NMR}$ (400 MHz, $\left.\mathrm{D}_{2} \mathrm{O}\right): \delta 2.34(3 \mathrm{H}, \mathrm{s}), 2.65(4 \mathrm{H}, \mathrm{m}), 3.36(3 \mathrm{H}, \mathrm{s}), 3.55(3 \mathrm{H}, \mathrm{s}), \quad 3.73(3 \mathrm{H}, \mathrm{t}), 4.15(1 \mathrm{H}, \mathrm{dd})$, 4.22(1H,m), 4.52(1H,dd), 7.98(1H,s).

Optical resolution of $( \pm)$-xanthinol. $(R)-(-)$-xanthinol (+)-camphor-10-sulfonate. Salts consisting of $( \pm)$-xanthinol and $(+)$-mandelic acid, $(+)$-tartaric acid, or $(+)$-3-bromocamphor-8-sulfonic acid, respectively, failed to crystallize. Initial experiments using $(+)$ camphor-10-sulfonic acid revealed that crystallization generally required 2-3 days to be complete. The diastereomeric salts formed from $( \pm)$-xanthinol $(1 ; 9.67 \mathrm{~g} ; 31.09 \mathrm{mmol})$ and (+)-camphor-10-sulfonic acid monohydrate $(7.78 \mathrm{~g} ; 31.08 \mathrm{mmol})$ were recrystallized four times from ethanol-acetone mixtures $\left(1: 2-3.5 ; 15-23 \mathrm{ml} \mathrm{g}^{-1} ;-18^{\circ} \mathrm{C}\right)$ yielding a salt $(4.86$ g) which on removal of the acidic moiety on a CG-400 column furnished xanthinol (1) exhibiting $[\alpha]_{\mathrm{D}}^{23}-3.92^{\circ}(c 20.4 ; \mathrm{EtOH})$ and the enantiomeric ratio of 53:47. The salt was then recrystallized twice from isopropanol-acetone mixtures $\left(1: 1 ; 7\right.$ and $7.5 \mathrm{ml} \mathrm{g}^{-1}$; room temperature) giving a product $(1.673 \mathrm{~g})$ which on decomposition on a CG-400 column yielded xanthinol $(1)$ with $\left.[\alpha]_{\mathrm{D}}^{20}-66.28^{\circ}(c) 9.45 ; \mathrm{EtOH}\right)$ and the enantiomeric ratio 93:7.

An alternative procedure using material from the mother liquors of the ethanol-acetone crystallizations (12.02 g; almost racemic), and more polar solvents, gave an even purer product. Recrystallization thrice from isopropanol (30, 25, and $35 \mathrm{ml}$; ambient temperature) followed by two crystallizations from ethanol-isopropanol mixtures $\left(1: 3.5 ; 9\right.$ and $12 \mathrm{ml} \mathrm{g}^{-1}$; room temperature) yielded $(R)-(-)$-xanthinol $(+)$-camphor-10-sulfonate $(3.286 \mathrm{~g})$, m.p. $171-172^{\circ} \mathrm{C} ;[\alpha]_{\mathrm{D}}^{19}-5.47^{\circ}(c 14.58 ; \mathrm{EtOH})$. Found: $\mathrm{C} 50.63 ; \mathrm{H}, 6.92 . \mathrm{C}_{23} \mathrm{H}_{37} \mathrm{~N}_{5} \mathrm{O}_{8} \mathrm{~S}$ requires: C, $50.81 ; \mathrm{H}, 6.86$.

$(R)$-(-)-Xanthinol (1a). The acidic part of $(R)-(-)$-xanthinol (+)-camphor-10-sulfonate $(0.875 \mathrm{~g} ; 1,61 \mathrm{mmol})$ was attached to a CG-400 column giving $(R)-(-)$-xanthinol $(1 a ; 0.486$ g; $97 \%$ ) as a colourless oil which solidified on standing at $+5^{\circ} \mathrm{C}$. The solid material was recrystallized from acetone-pentane at $+5^{\circ} \mathrm{C}$. M.p. $87-88^{\circ} \mathrm{C} ;[\alpha]_{\mathrm{D}}^{20}-76.54^{\circ}$ (c 8.1; 
EtOH); calculated: $[\alpha]_{\mathrm{D}}^{20}-77.07^{\circ}$, based on the rotation observed above for the $93: 7$ mixture; $\mathrm{m} / \mathrm{z}$ : as for ( - )-xanthinol $(1) ;{ }^{1} \mathrm{H} \mathrm{NMR}\left(300 \mathrm{MHz}, \mathrm{CDCl}_{3}\right): \delta 2.41\left(\mathrm{~N}-\mathrm{CH}_{3}, \mathrm{~s}\right), 2.50$ (H-3', dd, $J 12.5$ and 8.6 Hz), 2.65 (H-3', dd, $J 12.5$ and $4.3 \mathrm{~Hz}), 2.80\left(\mathrm{H}-5^{\prime}, \mathrm{m}\right), 3.06(2 \mathrm{OH}$, broad s), $3.41(\mathrm{~s})$, and $3.60(\mathrm{~s})$ (ring $N$-methyls), $3.70\left(\mathrm{H}-6^{\prime}, \mathrm{t}, J 5.3 \mathrm{~Hz}\right), 4.12\left(\mathrm{H}-2^{\prime}, \mathrm{m}\right), 4.25$ $\left(\mathrm{H}-1^{\prime}\right.$, dd, $J 14.0$ and $\left.7.0 \mathrm{~Hz}\right), 4.58\left(\mathrm{H}-1^{\prime}\right.$, dd, $J 14.0$ and $\left.2.5 \mathrm{~Hz}\right), 7.75(\mathrm{H}-8, \mathrm{~s})$. CD curve of (1a): see Fig. 1.

Partially purified (S)-(+)-xanthinol (1b). The mother liquor from the second crystallization from isopropanol $(25 \mathrm{ml})$ was concentrated in vacuo leaving an oil $(1.945 \mathrm{~g})$ which was crystallized $(1.284 \mathrm{~g})$ from ethanol-acetone $\left(5 \mathrm{ml}\right.$ of each; $\left.-18^{\circ} \mathrm{C}\right)$. M.p. $118-135^{\circ} \mathrm{C} ;[\alpha]_{\mathrm{D}}^{20}$ $+21.34^{\circ}$ (c 18; EtOH); ${ }^{1} \mathrm{H}$ NMR $\left(300 \mathrm{MHz}, \mathrm{D}_{2} \mathrm{O}\right)$ : similar to that of the corresponding salt with $(R)-(-)$-xanthinol $(a)$. A portion of the salt $(1.08 \mathrm{~g})$ was decomposed on a CG-400 column yielding xanthinol $(0.570 \mathrm{~g})$ with $[\alpha]_{\mathrm{D}}^{20}+26.70^{\circ}(c 7.11$; EtOH $)$. The enantiomeric composition was found to be 67:33 using the method of Pirkle et al. ${ }^{4,5}{ }_{\mathrm{H}}$ NMR: similar to that of $1 a$ and $\mathrm{m} / \mathrm{z}$ : as for 1 , respectively.

$(R)-(-)$ - and $(S)-(+)$-Proxyphylline $(2 a$ and $2 b)$. The syntheses of $(R)$ - and $(S)$ proxyphylline (2a and $2 b$ ) with enantiomeric ratios $R: S=98.2: 1.8$, and $S: R=98: 2$, respectively, have been described previously. ${ }^{6,7} \mathrm{CD}$ curves: see Fig. 1.

Acknowledgements. The authors are indebted to Dr. Kristen Fretheim and Dr. Ole J. Harbitz, the Norwegian Food Research Institute, N-1432 ÅS-NLH, Norway, for recording the CD curves, and to Astra Farmas $\varnothing$ ytiske A/S, N-1473 Skårer, Norway for a generous gift of xanthinol nicotinate.

1. Bestian, W. Ger. Pat. 1,102,750, March 23, 1961.

2. Stamm, H. Arzneim.-Forsch. 12 (1962) 679.

3. Bartoli, G., Frandoli, G. and Spreafico, P.L. Therapiewoche 27 (1977) 575.

4. Pirkle, W.H., Sikkenga, D.L. and Pavlin, M.S. J. Org. Chem. 42 (1977) 384.

5. Pirkle, W.H. and Boeder, C.W. J. Org. Chem. 42 (1977) 3697.

6. Ruud-Christensen, M., Skjetne, T., Krane, J. and Aasen, A.J. Acta Chem. Scand. B 38 (1984) 331.

7. Selvig, K., Ruud-Christensen, M. and Aasen, A.J. J. Med. Chem. 26 (1983) 1514.

8. Fretheim, K., Egelandsdal, B. and Harbitz, O. Int. J. Pept. Protein Res. 25 (1985). In press.

Received March 19, 1985. 